\title{
Epidemics which never came: yellow fever (1883) and bubonic plague (1902- 1903) in Baja California
}

\author{
Arturo Fierros-Hernández ${ }^{1}$ and Alejandro Ayala-Zúñiga² \\ ${ }^{1}$ Instituto Holy Cross, Tijuana; ${ }^{2}$ Family Medicine Unit No. 39, Instituto Mexicano del Seguro Social, Tecate. B.C., Mexico
}

\begin{abstract}
This paper seeks to clarify the epidemic panorama that was generated in Baja California in the late nineteenth and early twentieth 20 th century's, specifically that occurred in 1883 and 1902, years in which it is claimed occurred epidemics of yellow fever and bubonic plague respectively. However, as demonstrated in our study they never occurred due to social-demographic conditions in the area.
\end{abstract}

KEY WORDS: History. Epidemics. Vectors.

\section{Introduction}

With the perspective conferred by scientific, medical and epidemiological advances, reflections that have been generated, in addition to the conceptual tools historians have worked in, we are allowed to observe epidemiological phenomena of the past and thus being able to make a reconstruction with adherence to reality.

Some authors have pointed out that, in Baja California*, epidemics appeared that were related to diseases caused by vectors, such as yellow fever in $1883^{1,2}$ and bubonic plague in $1902^{3,4}$. Such claims were made based on documentation of the epoch, written by people with different trades and professions (with physicians standing out) not specialized in epidemiology, which caused for the concept of epidemic to be generalized and indistinctly used, which is a situation that produces an information bias, influenced

* During the period studied in the present article, Baja California had the status of District, it was the Baja California Northern District until after 1931 and stopped being it and became a Federal Territory. In 1952, it was granted the geopolitical denomination of State. by temporality and under-specialization. There are parameters to define an epidemic, which can be described in terms of three basic quantifiable variables: people, time and space ${ }^{5}$.

This article has the following objectives: 1) historicize the concept of epidemic and its meaning over time, and 2) to conceptually redefine the epidemics that occurred in Baja California during the referred years, based on a hybrid descriptive approach that rescues and relates elements of epidemiology and social sciences, as a sort of an interdisciplinary bridge $e^{6,7}$.

\section{The concepts of epidemic and epidemiology}

Currently, an epidemic is considered to be "a disease that is present in a community or population at a high percentage; when the disease spreads to inhabitants of several countries, we can speak of a pandemic".

The use of the concept of epidemic in the western literature is quite ancient ${ }^{9}$. It was Hippocrates of Kos (460-385 B.C) who used the term epidemeion, referring to the act carried out by the physician when he

\footnotetext{
Correspondence:

Arturo Fierros-Hernández

Virrey Luis de Velazco, 8

Col. Anexa Buena Vista

C.P. 22414 Tijuana, B.C., México

E-mail: arturofierrosh@gmail.com
}

Date of reception: 09-09-2016

Date of acceptance: 01-12-2016

DOI://dx.doi.org/10.24875/GMM.M18000120
Gac Med Mex. 2018;154:94-99

Contents available at PubMed www.gacetamedicademexico.com 
visited a population, without the current conceptualization of the term being reflected ${ }^{5}$.

During the Middle Age, in current Barcelona, several treatises (in Latin and Catalan) were published addressing the plague, which over time would acquire the adjective "black" and, later, "bubonic". In 1348, Jacme D'Agramont published Regiment de presrvació de pestilencia; by 1365 , Sanç de Ruidor, physician of the queen of Aragon, brought to light Régimen contra epdemian; in 1370, Joan Jacme, physician and teacher at Montpellier School of Medicine, published Contra epidemian. Of note, the purpose of the referred works was to generate a series of rules for the fight and prevention of disease. The authors use the word "epidemic" to refer to the appearance and persistence of the plague in an indistinct and plain form. There was no universal and valid criterion to define it, not even in the medieval medical field ${ }^{10}$, let alone among people who were foreign to the profession.

With the passage of time, the concept of epidemics became popular, motivated by the boom of treatises about the transmittable pathologies that were most common among the population (such as plague and smallpox), which carried in the title the word "epidemic". In Cyclopedia: or, An Universal Dictionary of Arts and Sciences, published in England by Ephraim Chambersin in 1728, an epidemic is defined as "the disease that is transmitted from one person to another: for example: the plague, smallpox, scurvy [or whatever was thought to be contagious in those days], etc., which arises from some corruption or malignancy in the air, which takes over a large number of people in a short time in villages [an idea that had to do the transmission of diseases through miasma]. This type of diseases occur in every types of people, regardless of age, sex, social status, as a result of a common or general cause"11. In L'Encyclopédie o Dictionnaire raisonné des sciences, des arts et des métiers, published between 1751 and 1772 by Denis Diderot and Jean le Rond d'Alembert in France, the definition of epidemic is similar to the definition of the encyclopedia published by Chambersin, but it is even more specific. In the first place, it refers to an epidemic as "a disease that affects in a time and space a large number of people of different sex and social status, who show the same symptoms, that afflicts the majority, of different villages". It also refers that the term was used in different forms by Herman Boerhaave (1638-1738) and other authors of that epoch. The definition is accompanied by the concept of epidemic disease, which "is that which sporadically occurs in one or several places, where it prevails and establishes itself for some time. They are not one type, and even, on the contrary, they are very different, depending on the seasons they are preceded by and the consequences they have"12.

These (dictionary) definitions, delimit space and time: place and date where the disease occurs. It is probable that unanimous criteria to define it per se were not established, but with no doubt it left a mark of its passage through society. In another sense, the definitions retrieve part of the definition that was used by common people. Whichever the origin, they are observed to show two of the three variables current epidemiology takes into account.

Although the new concept incipiently was beginning to be shaped within the public sphere, little had changed in the medical field. During the $19^{\text {th }}$ century, medicine was firmly consolidating itself within the scientific field. In 1854, cholera ravaged several parts of the world. Some analysts classify this historical moment as the third cholera pandemic ${ }^{13}$. At that moment, the mortality rate was very high. Only in England, 11,000 people died, 4.5 per every $1000^{14}$. It was precisely in that country and moment that the variable "people" $\dagger$ was taken into account in a scientific study by John Snow, who observed that the districts of the southern area of London concentrated the highest number of cases in absolute terms and accounted for the highest mortality rate, which was much higher than that of the rest of the city ( 8.0 and 2.4 deaths per 1000 population, respectively) $)^{15}$.

Snow's studies led him associate the three variables in a multi-causal form to explain the cholera outbreak that spread in the southern area of London. His reflections implicitly suggested that the time and space where disease occurs are essential to understand an epidemic, but also the number of infected subjects and deaths occurred.

Doctors and historians consider Snow as the father of epidemiology because, in his study, he considered that social and geographic factors accounted for a series of epidemiological problems.

The epidemiology field of study is relatively young; some scholars still debate about its age. There are some who attribute its origins to classical Greece and take Hippocrates as one of the first exponents, while

\footnotetext{
Throughout history, data have been collected on the number of deaths occurred every time any population, country or region is attacked by some disease; still, these data were not used to perform a study as in the case of Snow.
} 
others choose the point of view of considering that eastern civilizations were the creators of the first notions of epidemiology9.

Epidemiology current definition is with no doubt variable ${ }^{\ddagger}$, and its meaning has been diversified because it has historicity, although owing to its institutionalization as a medical science, there is generalized consensus on its definition: branch of public health that has the purpose to describe and explain the dynamics of population's health, and to identify the elements that comprise it and understand the forces that drive it, in order to intervene in the course of its natural development. Currently, it is accepted that, to meet its purpose, epidemiology investigates the distribution, frequency and the determinants of health condition in human populations, as well as the modalities and impact of the social responses implemented to address them ${ }^{9}$. Current epidemiological research studies factors of some diseases that are derived from social factors such as substance abuse, obesity and undernourishment, among many others.

However, this would have been unthinkable during Snow's epoch or even in the ensuing years, early in the past century. By the end of the $19^{\text {th }}$ century, for example, the Oxford English Dictionary quotes a text of an English physician named Parkin, published in 1873 , where he states that epidemiology is the "branch of medical sciences that studies epidemics". And this definition was included in the Oxford English Dictionary 1988 edition $^{16}$.

Epidemiology emerges owing to the need to study the sociodemographic repercussions of infectious-contagious diseases. A fundamental aspect was the consolidation of bacteriology and microbiology within the medical field, mainly encouraged by Rudolph Virchow (1821-1902), Louis Pasteur (1822-1895) and Robert Koch (1843-1910) investigations. For example, between 1862 and 1878, Pasteur discovered the cause of microbial-origin diseases, which triggered a series of investigations in search of the cause of diseases, since even when at his moment Snow found the social causes of the cholera epidemic that ravaged southern England, he didn't understand the etiology of cholera, in a strict sense, the primeval cause of the disease: a bacterium.

‡ In 1973, Dr. Aníbal Osuna, "a distinguished Venezuelan hygienist, gathered 28 concepts related to epidemiology, by means of which he accounted for the lack of agreement between authors about what until those days was understood by epidemiology".
Laboratory investigations enabled doctors to delve in the knowledge of diseases, which gave rise to the first epidemiological revolution in the last quarter of the $19^{\text {th }}$ century. William Henry Welch defines this period as the most extraordinary in the history of medicine, and says that today it is almost impossible to imagine the enthusiasm and victorious spirit that was awakened, not only among physicians, but also among the public, as a result of these discoveries ${ }^{17}$. Bacteriology was with no doubt one of the key pieces in the emergence of epidemiology, as tropical medicine also was.

By 1890, the world was to see the emergence of so-called tropical medicine, supported by bacteriologists and microbiologists who, in the referred timeline, were sent to European colonies in Asia and Africa by the Koch and Pasteur institutes located in Europe, in view of the threat of new diseases that decimated the white populations that pretended to live in the tropics. Thus was tropical medicine born, but as Sandra Caponi stated, knowledge on bacteriology and microbiology was not the only one that led to the birth of this medical science, but also biogeography, which legitimized the idea of the existence of local causes linked to specific vegetation, insects and animals that intervene in the production of particular diseases, as well as entomology, protozoology and natural history, which were tested in America ${ }^{18}$.

During the first decades of the $20^{\text {th }}$ there were important research experiences that contributed to refine the concept of epidemic. This fact is not casual, since it coincides with demographic, social, economic and political changes that contributed to the spread of many diseases, such as cholera, the plague and respiratory diseases, which generated a propitious environment for the study of epidemic phenomena. However, it wasn't until the second decade of the $20^{\text {th }}$ century that the medical and civilian community observed the birth of epidemiology: a discipline with theoretical bases and systematic study procedures.

In 1927, epidemiology was admitted to be a science, but limited to the "study of infectious diseases natural evolution". It was also claimed that it was an "inductive science, interested in describing the distribution of disease". Four years later, Stallybrass reinforced the idea that epidemiology should circumscribe to the study of infectious diseases, to indicate the specificity of transmittable disease and to identify the primary factors for its dissemination, which he classified as germ, vector and field ${ }^{16}$. 
By the end of the $19^{\text {th }}$ century and early in the $20^{\text {th }}$, the USA sent his doctors (mainly dependent of the war and navy department, and who then depended on state health institutions) to study epidemiological phenomena where there its interests were being affected, mainly owing to its expansionist posture in economic terms, since many diseases on their exponential form limited their exports and imports ${ }^{2}$. However, it was not until 1922 that the epidemiology subject started being taught at the Harvard School of Public Health ${ }^{19}$.

Due to the above, it is possible claiming that many USA and Mexican physicians lacked a clear training on that subjects and were unaware of the scientific meaning of events such as endemic, epidemic and pandemic; concepts about which they had a subjective, and in a certain sense, even popular idea.

\section{Yellow fever (1883)}

By the end of the $19^{\text {th }}$ century, yellow fever on its urban modality was endemic in some ports of the Gulf of Mexico ${ }^{1,2}$. The Aedes aegypti mosquito was transmission initial vector, since by ensuring its existence and life cycle, it established flavivirus existence and propagation. As it is well known, the vector arthropod feeds on blood and nests on stagnant water ${ }^{7}$. Aedes females deposited eggs in water containers that travelled with people; some probably hatched during the journey, other maybe were emptied and restarted the cycle. The opening of new routes with the use of steam technology in ships and trains, and the broadening of railways, facilitated the propagation of the vector and yellow fever across the Mexican territory, reaching some ports in the Pacific Ocean, such as Oaxaca, where it arrived in 1877. However, that was not the only known route followed by the vector to reach the Pacific costs. It also travelled from north, from the USA, where it had appeared in 1793 in current states of New York and Philadelphia, with about 4044 deaths, more than $10 \%$ of the population ${ }^{20}$.

With the creation of new settlements and the emergence of some cities in the north of Mexico and south of the USA, Aedes found new homes with favorable climates and environments, since it did not infect at below $62{ }^{\circ} \mathrm{F}$. In 1882, the fever appeared in some villages along the Rio Grande in both countries. Apparently, the disease entered via Matamoros ${ }^{21}$, and also it is highly probable that it entered via New Orleans. Those places had much contact with the Caribbean region, which was considered to be unhealthy ${ }^{22}$.
In 1883, there were news on the appearance of yellow fever at some ports and cities that are part of the northwestern Pacific coast. In the month of August, a telegram was sent to the President from Mazatlán, Sinaloa, informing about the havoc the disease had caused. According to the reports, morbidity was 4000 people and mortality 106, out of which, the majority were reported to be recently-arrived foreigners ${ }^{7}$.

The disease had arrived to Mazatlán by the sea from Panama, on board of the San Juan steamboat, and entered Sonora in the same way on board of the Newbern steamboat, which came from San Francisco, with a port call in Mazatlán, where apparently two people contracted the disease. Since its incubation period is 3 to 6 days, the individuals did not experience symptoms until 3 days after having called on port ${ }^{23}$. By September 1883, the disease had spread inland, as it was the case of Sonora, where it reached Hermosillo, Pueblo de Seris and Ures. Similarly, it spread between other northwestern Pacific ports, since some people fled the places where deaths occurred due to the fever. One of the main escape routes was the one covered by California Steamboats Company, which travelled from Mazatlán to San Francisco, and touched La Paz, Guaymas, Cabo San Lucas, Bahía de la Magdalena and Ensenada de Todos los Santos. Another was the accelerated line of Golfo de Cortés steamboats between Guaymas and Manzanillo, which touched Altata, La Paz, Mazatlán, San Blás and Chamela ${ }^{24}$.

Between the end of August and the beginning of September 1883, yellow fever had appeared in La Paz, Baja California Sur, in spite of the significant existence of the vector in the zones. Local authorities declared the presence of the fever official on September 5 through a communication addressed to the minister of the interior, where it was stressed that the disease had arrived via a sea vessel coming from Mazatlán ${ }^{25}$.

To aid the attacked zones, the government assigned an amount of 6297.33 pesos, which were distributed between Mazatlán (2518.93), Guaymas and HermosilIo (22067.03), San Blás (503.79), Manzanillo (503.79) and La Paz (503.79), where a little over $3 \%$ of the population died, which at that moment was comprised by 3554 inhabitants $^{24}$.

Although it reached to Baja California Sur, it did not spread to the north, i.e., Baja California, as Carrillo and

$\S 10$ days after having been infected by the flavivirus, the vector remains infectious up to 1 or 2 months, which is the arthropod's half-life. 
Rozón have stated, and it even didn't touch Ensenada, the most important port. As García and Salcedo state: "It ravaged Mazatlán from August to December 1883, and directly affected current states of Nayarit, Sinaloa, Sonora, Baja California Sur and, indirectly, Jalisco and Colima. The population mobilization caused by the epidemic had two directions: south, towards the San Blas port, from the old Jalisco Tepic canton; and north, towards the ports of Guaymas in the State of Sonora and until La Paz in Baja California [Sur]"'.

Probably the confusion existing about the yellow fever arrival to Baja California originates in the sources consulted by Ronzón and Carrillo, where the references to Baja California appear without specifying whether it is the Southern Jurisdiction (current Baja California Sur), Central Jurisdiction or Northern Jurisdiction, with both the latter being part of current Baja California. This issue also occurs in the article by José Rivas and Edith González entitled Epidemias y economía en la Baja California durante el régimen porfiriano, although villages belonging to the current state of Baja California Sur are mentioned therein, and the confusion for those who know the region is therefore inexistent**.

\section{Bubonic plague (1902-1903)}

During the years of 1902 and 1904, a bubonic plague epidemic occurred in San Francisco (USA) and Sinaloa (Mexico). According to some reports, the plague caused 113 deaths in San Francisco ${ }^{26}$ and 582 in Sinaloa ${ }^{27}$.

In 1889, the disease had arrived to San Francisco in a ship coming from Japan, according to reports of the US authorities. In the summer of 1900 , the plague appeared in San Francisco ${ }^{28}$, The first case was reported in May $21^{29}$. On May 24, Walter Wyman (Public Health General Supervisor of the US) informed Eduardo Liceaga (chairman of the Public Health High Council of Mexico) that six people with the disease had been detected. On December 11, 1902, Walter Wyman contacted Eduardo Liceaga again and stated that the plague had appeared in Ensenada, Baja California. Wyman recommended for Samuel Bates Grubbs (a doctor of the bacteriology laboratory from that

\footnotetext{
** Baja California and Baja California Sur geopolitical delimitation has been addressed by local historians, who have found that the Californias became High California (current US California) and Low California (current Baja California Sur and Baja California); in turn, Low California was divided into three legal jurisdictions during the decade of 1870 , and in 1888 , it was divided into two Districts, ending up as South and North.
}

department) to be sent to Ensenada, which was agreed by Mexican authorities in charge of that area. That same year, people who arrived to Ensenada coming from San José del Cabo, Baja California Sur, claimed that the plague had appeared in that town in $1901^{3}$. After being persuaded by Wyman, Grubbs travelled to Los Angeles, California, where he took the Curacao ship and arrived to Ensenada on December 17, 1902. By the end of that month he had learned from a locally residing doctor, Bertrand $\mathrm{H}$. Peterson ${ }^{28}$, that very isolated cases of plague had occurred in that village ${ }^{3}$. With the references offered by Peterson, Grubbs located the first cases in December 1901, in addition to making several investigations in the village, including examining the corpses of a man who had died in jail and another who died at home, of which he was able to extract samples. About the latter episode, Grubbs wrote: "He had a typical bubo, great swelling of the axilla caused by the bites of the fleas that infected him. I pricked the gland with a hypodermic needle to extract part of the fluid; the family watched me from near the door to verify that I kept my promise of not using a knife. Given the circumstances, I have performed the examination as deeply as I could"30.

Grubbs was not the only one to report infected subjects in the Baja California port. On June 6, 1903, two cases were reported in Ensenada by American authorities, although mortality of plague in the area is not known, we know that there were four confirmed cases detected by American authorities, but none by Mexican Authorities ${ }^{29}$.

By then, Ensenada had around 2000 inhabitants $^{31}$, i.e., a mortality of only $0.2 \%$ was reported, and an epidemic could therefore not have occurred in Ensenada, let alone in Baja California. Moreover, in the death certificates of the main settlements (Ensenada, Tijuana, San Quintín and Tecate; the Real del Castillo, El Rosario, Santo Tomas, Santo Domingo, San Telmo and San Vicente villages; El Álamo, Juárez, Calmalli and Jacalitos mining towns; and the Guadalupe, La Grulla, Santa María, La Huerta, El Encino, Cañada Verde, El Ciprés and Los Alisitos ranches), no single reference to anybody dying from the plague in Baja California is found. However, as David Piñera and Jorge Martínez state, "the causes of death are difficult to determine given the sparse and inaccurate information of death certificates: shock, flank pain, paralysis, indigestion, urine retention, chest disease or intestinal catarrh"32. In other words, in official records of between 1902 and 1903, bubonic plague does not exist as a cause of death. 


\section{Final considerations}

The epidemiological panorama that took shape in the Mexican northwestern Pacific by the end of the $19^{\text {th }}$ century and beginnings of the $20^{\text {th }}$ was not that which has been indicated in the literature on the subject. This process is clarified when the concept of epidemic is historicized and by understanding it as a conceptual unit that is delimited by a figure. The described epidemiological data have not been categorized within the modern conceptual framework of epidemics due to the lack of unanimity in criteria for their definition, lack of epidemiological reports by doctors, lack of specialization and limited performance of necropsy studies.

For this reason, it is understood that an epidemic of yellow fever and bubonic plague never took place in Baja California in the studied period, since the deaths that occurred do not cover the parameter required for the introduction of the disease to be considered an epidemic.

\section{References}

1. Ronzón J. Sanidad y modernización en los puertos del Alto Caribe. 1870-1915. México: Universidad Autónoma Metropolitana; 2004.

2. Carrillo AM. Guerra de exterminio al "fantasma de las costas". La primera campaña contra la fiebre amarilla en México, 1903-1911. En: Agostoni $C$, coordinador. Curar, sanar y educar. Enfermedad y sociedad en México, siglos XIX y XX. México: Universidad Nacional Autónoma de México; 2008. p. 219-56.

3. Carrillo AM. ¿Estado de peste o estado de sitio? Sinaloa y Baja California, 1902- 1903. Hist. Mex. 2005;54:1049-103.

4. Fierros A. Historia de la salud pública en el Distrito Norte de la Baja California 1887-1923. México: Centro Cultural Tijuana; 2014.

5. Alvarado J. Epidemias, endemias y conglomerados: conceptos básicos. RFM. 2000;48:175-80

6. Sánchez G. El modelo histórico-epidémico: el caso de la peste bubónica en Mazatlán 1902-1903. En: Cházaro L, editor. Medicina, ciencia y sociedad en México siglo XIX. Michoacán: Colegio de Michoacán; 2002. p. 137-58.
7. García J, Salcedo A. Fiebre amarilla en Mazatlán, 1883. Espiral. 2006:35:121-47.

8. Molina A, Márquez L, Pardo C. El miedo a morir. Endemias, epidemias y pandemias en México: análisis de larga duración. México: Instituto Mora; 2013.

9. Garrido F, López S, Hernández M. Desarrollo histórico de la epidemiología: su formación como disciplina científica. SPM. 2000;42:133-43.

10. Betrán J. La peste en la Barcelona de Los Austrias. Madrid: Milenio; 1996.

11. Ephraim C. Cyclopedia, or, an universal dictionary of arts and sciences. Londres; 1728. p. 323.

12. Diderot D, D'Alembert J. Encyclopédie ou dictionnaire raisonné des sciences, des arts et des métiers. Vol. 3. Génova: Imprimeur de la République/Société Typographique; 1778. p. 789.

13. Porter R. Historia de la medicina: desde la antigüedad hasta nuestros días. México: Taurus; 2003.

14. Winterton W. The Soho cholera epidemic 1854. HM. 1980;8:11-20.

15. Cerda J, Valdivia G. John Snow, la epidemia de cólera y el nacimiento de la epidemiología moderna. RCI. 2007;24:331-4.

16. Moreno S, Corcho A, Moreno A. Notas históricas sobre el desarrollo de la epidemiología y sus definiciones. RMP. 1999;66:110-4.

17. Carrillo A. La influencia de la bacteriología francesa en la mexicana en el periodo de su institucionalización. QUIPU. 2012;2:193-219.

18. Caponi S. Trópicos, microbios y vectores. HCSM. 2002;9:111-38.

19. Terris M. La epidemiologia y la salud pública: orígenes e impacto de la segunda revolución epidemiológica. RSHP. 1994;68:5-10.

20. Oldstone M. Virus, pestes e historia. México: Fondo de Cultura Económica; 2003.

21. Ruiz S. Fiebre amarilla en México, a lo largo del Bravo, y en el litoral del Pacífico. Gac Med Mex. 1884:4:73-85.

22. Ronzón J. El panorama epidémico en el Golfo de México. Los puertos de La Habana, Veracruz y New Orleans en la segunda mitad del siglo XIX. PB. 1998:4:167-79

23. Chin C. El control de las enfermedades transmisibles. Washington: Organización Mundial de la Salud; 2001.

24. Félix H. Cuando la muerte tuvo alas. La epidemia de fiebre amarilla en Hermosillo (1883-1885). México: Colegio de Sonora; 2010.

25. Rivas J, González E. Epidemias y economía en la Baja California durante el régimen porfiriano. En: Méndez M, editor. Diversidad social, política y económica en distintos tiempos y espacios regionales. México: Universidad Autónoma de Tlaxcala; 2015. p. 129-45.

26. Echenberg M. Plague ports: the global urban impact of bubonic plague: 1894-1901. Sacramento: New York University Press; 2007. p.113.

27. Candil RA, Romero CR, García YY. El brote de peste en Mazatlán, Sinaloa, México (1902-1903). LAB. 2009;21:19-23.

28. Skubik M. Public health politics and the San Francisco plague epidemic of 1900-1904. Tesis. California: San Jose State University; 2002.

29. Association of Schools of Public Health. Public health reports. Health Serv Rep. 1900- 1903

30. Grubbs S. By order of the surgeon general 1871-1942. Pennsylvania: Mitchel Printing Company; 1943.

31. Samaniego M. Nacionalismo y revolución: los acontecimientos de 1911 en Baja California. México: Centro Cultural Tijuana; 2008.

32. Piñera D, Martínez J. Datos para la historia demográfica de Baja California. Causas de defunción. Mexicali: Instituto de Investigaciones Históricas; 1991. 